\title{
Olavo Bilac e a questão da instrução no Brasil (1897-1908)
}

\author{
Olavo Bilac and the issue of education in Brazil (1897-1908)
}

\section{Thiago Roza Ialdo Montilha}

Doutorando pelo Programa de Pós-graduação em História Social da Universidade Federal do Estado do Rio de Janeiro vcthiago@hotmail.com

\begin{abstract}
Resumo: O presente artigo pretende analisar a perspectiva do poeta e jornalista Olavo Bilac sobre a questão da instrução no Brasil de seu tempo. O período enfocado é delimitado pelos anos situados de 1897 a 1908 e o espaço privilegiado em nossa análise é a cidade do Rio de Janeiro. Em linhas gerais, almejamos compreender quais razões levaram Olavo Bilac a atribuir enorme importância à questão da educação e alguns dos diversos significados e funções que conferiu à mesma. As fontes primárias selecionadas para este artigo são as crônicas publicadas pelo escritor na imprensa de sua época.
\end{abstract}

Palavras Chaves: Intelectuais, Educação, Olavo Bilac.

\begin{abstract}
This article analyzes the perspective of the poet and journalist Olavo Bilac on the issue of education in Brazil of his time. The reference time frame consists of the years located between 1897 and 1908, and the privileged space in our analysis is the city of Rio de Janeiro. In broad outline, we aim to understand more deeply which reasons led Olavo Bilac to attach great importance to that matter and some of the different meanings and functions that he has given to it. It should be noted that the primary sources selected for this study were the chronicles published by Olavo Bilac in the press of his day.
\end{abstract}

Keywords: Intellectuals, Education, Olavo Bilac. 
No decorrer da virada do século XIX, o homem de letras Olavo Brás Martins dos Guimarães Bilac (1865-1918) ${ }^{1}$ construiu a sua trajetória (BOURDIEU, 1996) de consagração intelectual enquanto poeta e jornalista de destaque. Tal ascensão profissional, que atribuiu significativo capital simbólico (BOURDIEU, 1989: 145) à sua figura, teve como elemento marcante o seu engajamento na discussão das principais questões da sociedade brasileira de seu tempo. Nesse sentido, a análise que pretendemos realizar alinha-se a esta perspectiva, encontrando o seu devido embasamento historiográfico nos trabalhos elaborados por Antônio Dimas (DIMAS, 2006), Magali Engel (ENGEL, 2004; 2006; 2008; 2010), Álvaro Santos Simões Júnior (SIMÕES JÚNIOR, 2007) e Patrícia Hansen (HANSEN, 2007). A importância de tais abordagens reside no reconhecimento do engajamento intelectual de Olavo Bilac e na atenção dada às etapas basilares de sua trajetória, desde os seus momentos iniciais, caracterizados por sua dedicação à poesia e ao jornalismo, até sua maturidade, quando se dedicou às atividades militantes da Liga de Defesa Nacional.

Certos quanto ao perfil atuante de Olavo Bilac, sobretudo pelos diversos projetos de modernização que desenvolveu para a complexa realidade nacional ${ }^{2}$, temos como objetivo central analisar e melhor compreender a sua perspectiva a respeito da instrução no Brasil de sua época, não sendo exagerado afirmar que era ela, para o autor carioca, uma das questões mais importantes naquele alvorecer de século XX.

Para a concretização da abordagem proposta, gostaríamos de destacar que julgamos a seleção das fontes como ponto fundamental. Apreender as nuances do olhar bilaquiano perante a questão da instrução no Brasil, indubitavelmente exige uma criteriosa escolha do corpus documental a ser utilizado e nos traz uma primeira questão: que tipo de material produzido por Olavo Bilac, em sua extensa trajetória intelectual,

\footnotetext{
${ }^{1}$ Filho do médico Brás Martins dos Guimarães Bilac e de Delfina Bilac, Olavo Brás Martins dos Guimarães Bilac chegou a cursar as faculdades de Direito, em São Paulo, e de Medicina, no Rio de Janeiro, sem as ter concluído. Como muitos letrados de seu tempo, Bilac teve grande parte de sua subsistência diária garantida pelo funcionalismo público e pelas colaborações diárias na emergente imprensa da época. Sua trajetória intelectual assumiu várias "frentes"; ao longo da década de 1880 dedicou-se principalmente à poesia parnasiana, da qual se tornou um dos principais representantes, e a partir da década de 1890, pôs a sua veia literária a serviço de diversos periódicos de grande porte das cidades do Rio de Janeiro e São Paulo. Por fim, não devemos esquecer que Olavo Bilac, já na década de 10, passou à militância nacionalista através da Liga de Defesa Nacional, organização civil que ajudou a fundar e que lutou em prol de causas como a obrigatoriedade do alistamento militar e massificação da alfabetização popular (MAGALHÃES JÚNIOR, 1974).

${ }^{2}$ Olavo Bilac, no decorrer de sua trajetória intelectual, defendeu alguns projetos, em variados âmbitos, visando a modernização da sociedade brasileira, estando dentre os mais conhecidos a expansão do saneamento pelo país e o alistamento militar obrigatório.
} 
melhor alinha-se ao objetivo supracitado? Baseados em um panorama geral da produção intelectual bilaquiana, bem como cientes da inexorável incompletude que qualquer seleção de fontes carrega consigo, entendemos que o vasto conjunto de crônicas jornalísticas ${ }^{3}$ do autor seria o mais adequado, principalmente pelo caráter opinativo que tais escritos possuíram (SIMÕES JÚNIOR, 2003-2004).

Um outro aspecto relacionado ao objeto de análise proposto e que previamente deve ser destacado, refere-se ao recorte cronológico estabelecido. Levando em conta que Olavo Bilac se dedicou ao jornalismo opinativo por quase duas décadas, tendo iniciado no ramo por volta de 1890 e abandonado tais atividades em meados de 1908, e a importância que a imprensa teve para sua ascensão no mundo intelectual coevo, adotamos o ano de 1897 como marco inicial, sobretudo por sua importância simbólica, uma vez que nele, mais precisamente em março, Olavo Bilac fora convocado a substituir Machado de Assis nas colunas da popular e "consagradora"4 Gazeta de Notícias. Por outro lado, quanto ao marco final, o ano de 1908 justifica-se por trazer à tona o abandono, por parte do cronista Bilac, das atividades jornalísticas que até então desempenhara com enorme afinco. A partir daí as contribuições bilaquianas na imprensa seriam bastante esporádicas, em geral poesias, e sem o vínculo que marcou as passagens do autor carioca por diversos periódicos, tais como: O Estado de São Paulo, Correio Paulistano, Kosmos, A Notícia, A Bruxa, A Cigarra, entre outros. Vale destacar que a saída de Olavo Bilac da grande imprensa foi explicada por Álvaro Santos Simões Júnior como devida a acusações sofridas pelo autor de que teria recebido significativa subvenção do Itamaraty (27 contos de réis), graças à influência de seu amigo e renomado diplomata, o barão do Rio Branco (SIMÕES JÚNIOR, 2007: 66), para fundar, junto de Medeiros e Albuquerque, uma agência de informações para homens de negócios, a chamada Agência Americana.

Em âmbito teórico-metodológico incorporamos o conceito de campo intelectual (BOURDIEU, 1968) tal como trabalhado pelo sociólogo francês Pierre Bourdieu, sendo ele fundamental para uma adequada compreensão da perspectiva esboçada por Olavo Bilac sobre a questão da instrução no Brasil. Inclinados pela ideia de Bourdieu de que "O que faz com que um pensador pertença a sua época [...] são antes de mais nada as

\footnotetext{
3 As crônicas jornalísticas analisadas foram publicadas nos periódicos: Gazeta de Notícias, Correio Paulistano e Kosmos.

${ }^{4} \mathrm{O}$ próprio Olavo Bilac demonstrou perceber, em crônica datada do aniversário da folha, o poder de consagração que a mesma tinha para a carreira dos homens de letras de seu tempo. Relembrando a sua juventude, o cronista dissera: "a Gazeta, naquele tempo, era a consagradora por excelência. Não era eu o único que a namorava; todos os da minha geração tinham a alma inflamada nessa mesma ânsia ambiciosa" (BILAC, 1903: 1-2).
} 
problemáticas e as temáticas obrigatórias nas quais e pelas quais pensa” (BOURDIEU, 1968: 141), julgamos plenamente legítimo considerar que a questão da instrução, tal como outras diversas problemáticas, era central para os círculos letrados nacionais da virada do século XIX, devido a uma quase generalizada preocupação com a modernização da nação brasileira. Neles inserido, e com posição de destaque, Olavo Bilac jamais deixou de ratificar a importância que a instrução teria na construção de um futuro de progresso social para o Brasil.

Portanto, partindo da interpretação de que o poeta-jornalista, em meio ao recorte cronológico definido, já se encontrava plenamente estabelecido e consagrado no campo intelectual, sobretudo pelo seu intenso envolvimento com as principais instâncias consagradoras da época, a exemplo da Academia Brasileira de Letras e da grande imprensa, em linhas gerais gostaríamos de analisar as nuances do posicionamento privilegiado que concedeu à instrução em seus planos de modernização do Brasil. Seguramente, a parte jornalística da produção intelectual de Olavo Bilac, como dissemos, devido ao seu caráter em grande parte opinativo, nos permitirá compreender, em termos mais específicos, alguns dos múltiplos significados e funções que atribuiu à urgente "tarefa" da instrução no país.

Não foram poucas as crônicas que Olavo Bilac dedicou ao tratamento da questão da instrução no Brasil e tamanha importância pode ser entendida como resultante de seu alinhamento favorável ao desenvolvimento do mundo burguês e liberal já consolidado na Europa ocidental daquela virada de século. Bilac, como grande parte da intelectualidade brasileira coeva, tinha o modelo de sociedade europeu como referencial para a modernização que tanto vislumbrava para a problemática realidade nacional. Nesse sentido, pode-se dizer que os traços que caracterizavam países como França e Inglaterra, tais como o seu desenvolvimento social e econômico, o seu florescimento cultural bem como a linha política liberal que seguiam, eram basilares ao poeta-jornalista que por diversas vezes foi à Europa e presenciara por si mesmo aquilo que entendia e afirmava ser "civilizado" (SIMÕES JÚNIOR, 2007: 175). Deve ser destacado que no decorrer do século XIX os esforços destes países ditos "civilizados" para a difusão da instrução, sobretudo pelas camadas populares, foram significativos e representavam justamente um dos pilares de sustentação do emergente modo de vida urbano, que exigia, em escala crescente, mão-de-obra apta aos exercícios profissionais que lhe eram típicos e cada vez mais complexos. Assim, certos quanto ao fato de que Olavo Bilac tinha esta ordem social como modelo para o "renascimento moral, material, e cívico" (BILAC, 1906d: 3-4) que 
desejava ver concretizado em terras nacionais, sendo exemplar a sua completa adesão aos conceitos burgueses de "civilização" e "progresso", podemos julgar tal posicionamento intelectual de sua parte como a principal "raiz" do grande apreço que revelou ter pela causa da educação no Brasil. Contudo, como veremos, a perspectiva bilaquiana sobre a instrução possuía muitas nuances e enfoques bastante diferenciados.

Enquanto intelectual extremamente atento à alarmante realidade que marcava a educação do país, Bilac reconhecia não somente os potenciais da expansão da instrução, mas também os nefastos efeitos que sua ausência, em determinados níveis e aspectos, havia causado ou poderia causar às mais diversas esferas da vida social.

Deste modo, inicialmente é forçoso ressaltarmos que a questão da instrução, para Olavo Bilac, encontrava-se inexoravelmente ligada a dois processos que considerava fundamentais: a consolidação da República e o fortalecimento do capitalismo no Brasil. Em primeiro lugar, vale ratificar que o poeta-jornalista foi um ardoroso republicano: durante sua juventude se envolveu ativamente com o republicanismo emergente no final do século XIX, e mesmo em sua maturidade, já voluntariamente restrito ao espaço da imprensa, não deixou de defender a República, embora não concordasse com as feições oligárquicas que esta acabara assumindo. Em segundo lugar, deve-se ter em mente que Olavo Bilac era plenamente favorável à ascensão do capitalismo no Brasil, sendo ilustrativo o valor que concedeu ao trabalho livre, que seria, a seu ver, meio de ascensão social, de concretização do progresso do país e também instrumento para a manutenção da ordem social (ENGEL, 2004: 10-11).

A partir deste conhecimento quanto ao alinhamento favorável do autor em relação à solidificação da República e do sistema capitalista, pode-se dizer que a questão da instrução era, no seu ponto de vista, detentora de um significado extremamente complexo, sobretudo em relação ao regime republicano, afinal, como Olavo Bilac demonstrou julgar, seria ela uma das ferramentas mais importantes para o seu progresso e aperfeiçoamento.

Neste âmbito, um primeiro ponto ao qual cabe destaque é o fato de que Olavo Bilac nos deixou vestígios que demonstram a sua plena concordância com a valorização dada à alfabetização no decorrer do processo de implantação da República, principalmente com a sua adoção como exigência para o exercício da cidadania política, ou seja, o voto. Segundo José Murilo de Carvalho, a alfabetização como condição para o exercício do voto na Primeira República, demonstrava a disposição das classes dirigentes envolvidas no processo, em excluir das instâncias decisórias justamente as camadas menos favorecidas da população, afinal, era seu intuito manter os baixos níveis de 
participação política e "Percebera-se que, no caso brasileiro, a exigência da alfabetização, introduzida em 1881, era barreira suficiente para impedir a expansão do eleitorado" (CARVALHO, 1987: 43-44). Em determinada crônica, datada de outubro de 1905, Bilac revelou o seu posicionamento favorável à exigência constitucional do letramento para o exercício do voto. Contudo, o escrito, oriundo da Gazeta de Notícias, revelava bem mais do que a sua simples concordância com a questão do letramento para o acesso à cidadania política na República:

Que o eleitor saiba escolher com independência e critério o seu candidato, ou que prefira dar ou vender um voto a um incapaz, - pouco importa! O que importa é que todo homem válido, sabendo ler e escrever, queira deste modo afirmar a sua vontade de ser cidadão, de ser eleitor, de ser alguém (BILAC, 1905b: 5).

Pode-se dizer que a instrução era a baliza determinante na afirmativa destacada, na qual o autor aberta e seletivamente prezava pelo voto daqueles cidadãos que considerava "válidos", ou seja, os alfabetizados. A partir deste trecho, especialmente da ideia de uma suposta "validez" inerente ao voto do cidadão letrado, é possível julgar que seria a instrução, aos olhos de Olavo Bilac, o elemento que capacitaria os comuns brasileiros iletrados a uma consciente e autônoma participação política através das urnas, prática esta, como certamente percebia o cronista, fundamental à legitimação simbólica do regime republicano. Bilac não esboçou esta perspectiva por diversas vezes, mas dela podemos depreender que, se apenas os cidadãos alfabetizados eram "válidos", ou seja, positivos à realização do processo decisório em questão, os demais, que não eram “alguém”, no seu modo de ver, não teriam capacidade e muito menos critério para exercer a sua cidadania política de maneira independente e racional, tendo em vista que a sua ignorância poderia colocá-los à mercê de sujeitos mais esclarecidos e mal-intencionados. No contexto da Revolta da Vacina, ao refletir sobre o papel das camadas populares iletradas no movimento, Bilac deixou clara esta perspectiva: "Quem não sabe ler, não vê, não raciocina, não vive: não é homem, é um instrumento passivo e triste, que todos os espertos podem manejar sem receio" (BILAC, 1904b: 3-4). Por outro lado, embora através do trecho destacado seja possível interpretar Olavo Bilac como plenamente concordante com a ideia de uma restrita participação política popular, desejada por boa parte das classes dirigentes e intelectuais da época, julgamos mais adequado compreender 
o seu posicionamento a respeito como exclusivamente favorável à exigência constitucional da alfabetização para o voto, tendo em vista o incômodo que por diversas vezes evidenciou em relação ao comum esvaziamento eleitoral do período republicano, devido, entre outros motivos, ao crônico analfabetismo brasileiro. Para o jornalista Bilac, o crescimento da participação eleitoral era fundamental, desde que constituído por eleitores esclarecidos e letrados, sendo o seu comparecimento às urnas indício da vitalidade cívica de que tanto necessitava aquela República de pleitos vazios e desvalorizados. Em ocasião de eleições municipais, em meados de 1905, o cronista carioca demonstrou o seu entusiasmo com o significativo número de eleitores que foram ao edifício do Conselho Municipal requisitar o seu diploma: "Que pode haver, de mais alegre e mais agradável, do que esse entusiasmo, com que trinta mil cidadãos se atiraram à conquista dos Diplomas? [...] Já não se dirá que somos uma imensa manada de carneiros indiferentes" (BILAC, 1905b: 5).

Enfim, a nítida valorização que o autor concedia à instrução, enquanto elemento de esclarecimento e capacitação intelectual, pode ser entendida como um importante componente de sua concordância com a alfabetização como exigência legal para o voto, sendo ilustrativo lembrar de sua perspectiva extremamente negativa a respeito da existência social do indivíduo iletrado, a seu ver, completamente incapaz de exercer a sua cidadania política: "um instrumento passivo e triste, que todos os espertos podem manejar sem receio" (BILAC, 1904b: 3-4).

As observações até aqui realizadas nos permitem ter alguma clareza quanto à importância que Olavo Bilac concedia à instrução como elemento que teria uma significativa contribuição no processo de consolidação da República. O poeta-jornalista, que sofreu na pele alguns dos momentos mais dramáticos do autoritário mandato de Floriano Peixoto, inclusive com a sua prisão em algumas ocasiões, tinha plena ciência do intrincado processo de estabilização que o regime republicano enfrentava na virada do século. Jamais lhe passaram despercebidos os importantes obstáculos que tiveram de ser enfrentados pelos governos coevos, tais como movimentos recalcitrantes à nova ordem estabelecida, a exemplo do sangrento conflito de Canudos, e a profunda exclusão social e política experimentada pelas camadas populares, o que sem dúvida em muito comprometia a possibilidade de adesão destas à nova institucionalidade. De todo modo, de acordo com Olavo Bilac, uma das maneiras de contribuir positivamente para a consolidação da República brasileira seria conquistar de nossas classes dirigentes a devida atenção para a questão da instrução, especificamente em seu nível primário, o que 
reconhecia ser bastante difícil em um contexto de parcos investimentos e obrigações legais para com a área educacional. Em inícios de 1905, quando se deparou com um projeto do presidente Rodrigues Alves, que visava à desapropriação da casa do marechal Deodoro da Fonseca, o jornalista carioca não hesitou ao enfatizar a necessidade de valorização do espaço educacional, ressaltando que na dita casa se encontrava uma escola primária que deveria ser mantida justamente para que se demonstrasse um real desejo governamental de honrar a República assim como a memória de um dos seus fundadores. A crônica que publicou na ocasião, revela-se importante principalmente pela perspectiva que esboçou quanto ao potencial que a instrução primária teria para o "florescimento" da República e pela crítica que fazia à negligente postura dos governos republicanos perante a área da educação. Dissera Olavo Bilac:

Não sei se o regime republicano pode florescer e frutificar bem, num país que conta no seu seio mais de dez milhões de analfabetos... O melhor meio de honrar o regime e honrar quem o fundou, é associar a memória do fundador à obra santa da instrução primária. Cada criança, das que daquela casa continuarem a sair sabendo ler e escrever, será mais uma criatura livre, capaz de defender, transformar esta República, - que, desgraçadamente, ainda parece pensar que pode merecer o nome de homem um animal incapaz de decifrar os caracteres do alfabeto... (BILAC, 1905a: 2).

Claramente percebe-se que incomodava bastante a Olavo Bilac o descuido dos governos republicanos frente à questão da instrução popular, assim como a sua constatação de que no Brasil ainda se contavam em milhões os analfabetos. E referente ao regime republicano, a partir das observações realizadas pelo autor, legitimamente depreendemos que, se houvesse a devida atenção dos profissionais da política nacional à causa da instrução, se estaria muito mais próximo do que então chamava por "transformar esta República" (BILAC, 1905a: 2), o que seria, em outras palavras, dar a ela uma identidade diferente daquela que possuía até então e que seguramente não entendia como positiva ou "moderna". Contudo, cabe frisar que, mais uma vez demonstrando entender a instrução como elemento de capacitação intelectual do indivíduo, Olavo Bilac retomava uma argumentação que a relacionava à solidez da República, porém, desta vez, na crônica em questão, julgamos que implicitamente constava a sua interpretação de que difundir a educação pelas camadas populares significava cultivar a possibilidade de uma radical 
mudança da realidade política brasileira, que eliminaria antigas problemáticas de seu cotidiano, tais como o esvaziamento eleitoral, o predomínio oligárquico e o voto de cabresto.

Por outro lado, indissociável desta visão do autor que entendia a instrução primária como capaz de habilitar o comum brasileiro à cidadania política e, em última instância, a contribuir positivamente para a consolidação da República, havia o seu olhar profundamente negativo, e muitas vezes abertamente veiculado, a respeito da existência social do indivíduo analfabeto no mundo contemporâneo, algo, a seu ver, abominável e completamente incompatível com o fenômeno da modernidade que tanto admirava. Através de sua produção cronística, Olavo Bilac ratificou publicamente o analfabeto enquanto elemento nocivo à sociedade brasileira e à ordem republicana, já que a sua ignorância trazia consigo inúmeros males em potencial, sendo ele não somente um animal destituído de importância social e política, mas um significativo obstáculo à instalação dos tempos de progresso e de civilização no Brasil, ou seja, à chegada definitiva da era de modernidade no país. Em verdade, para o poeta-jornalista, que tinha a sociedade europeia como referencial, a existência de um "povo", em termos sociais, políticos e culturais, estava inexoravelmente condicionada à sua alfabetização, deste modo, aos seus olhos, ’No Rio de Janeiro e, em todo o Brasil, os analfabetos são legião. E não há ‘povo', onde os analfabetos estão em maioria" (BILAC, 1904b: 3-4).

A ideia do jornalista carioca de que o analfabeto era incapaz de cumprir com a sua missão cívica de "defender [e] transformar esta República” (BILAC, 1905a: 2), ainda que sua condição fosse resultado de razões como o descaso governamental, era apenas parte de uma perspectiva mais ampla que tinha a respeito de problemáticas que considerava inerentes à falta de instrução popular no Brasil, sobretudo em seu nível primário. Um exemplo de questão que aparecia como mais uma "pedra no caminho" do progresso nacional e que o cronista Bilac demonstrou entender como em grande parte resultante do difundido analfabetismo brasileiro, era justamente a eclosão de momentos de desordem social, tais como as revoltas populares, a seu ver, completamente condenáveis, uma vez que apenas atravancavam o já difícil processo civilizatório teoricamente vivido pelo país. Nesse sentido, vale destacar o movimento da Revolta da Vacina, um dos mais importantes do período republicano e amargamente presenciado por Olavo Bilac. O envolvimento de segmentos populares bem como os estragos causados às ruas da capital foram alguns dos motivos do desgosto que o poeta-jornalista sentiu naquele final de 1904, ano que até então entendia como bastante positivo, principalmente pelo andamento apresentado pelas 
reformas urbanas do prefeito Pereira Passos: aos olhos de Olavo Bilac, tal reformulação das estruturas urbanas do centro da cidade tinha finalidades diversas, entendimento que demonstrou quando se pôs a descrever o seu contato com o resultado das obras: "E, pela Avenida em fora, acotovelando outros grupos, fui pensando na revolução moral e intelectual que se vai operar na população, em virtude da reforma material da cidade" (BILAC, 1905: 3). Contudo, a revolta eclodiu no mês de novembro e enquanto cronista atento aos fatos da capital, Bilac não deixou de expressar o seu descontentamento com a destruição que ela ocasionara e de identificar incisivamente aquelas causas que entendera como as principais para o início do movimento:

E eu perguntava a mim mesmo, embrutecido pelo espanto, que mágoa, que ressentimento, que receios, e que despeito pudera levar esta gente a um ato de tão completa insensatez, obrigando todo o Brasil a perder em um dia o que ganhara em quinze anos, revoltando-se contra um governo que só quer dar luz, avenida, saúde, árvores, limpeza, dignidade ao povo, dando dignidade aos que querem trabalhar, provendo os lares de pão, preparando a grandeza futura da pátria, que só ainda não é grande e bela por ser suja e despovoada... [...] E não há também em todas as cidades, como há aqui, uma tão considerável massa de gente ignorante, não sabendo ler nem escrever, e sempre disposta, pelo seu analfabetismo, a ouvir e a aceitar todas as desbragadas mentiras que os exploradores lhe impingem. Se esta cidade não estivesse tão cheia de analfabetos, ninguém lograria convencer a pobre gente ingênua das estalagens que o governo queria vaciná-los com caldo de ratos mortos de peste... (BILAC, 1904a: 1).

Ao mesmo tempo em que implicitamente apoiava a campanha de vacinação contra a varíola, proposta pela Diretoria Geral de Saúde Pública então comandada pelo cientista Oswaldo Cruz, Bilac ratificava na crônica em questão que o analfabetismo popular havia sido uma das principais causas para a eclosão da revolta que, a seu ver, não possuía quaisquer motivos para acontecer, já que a cidade do Rio de Janeiro finalmente era governada por um prefeito que só queria "dar luz, avenida, saúde, árvores, limpeza, dignidade ao povo" (BILAC, 1904: 1). Na parte final da crônica, publicada na Gazeta de Notícias, o autor reafirmava a ignorância popular como fator determinante para a ocorrida revolta, mas sugeria que a principal maneira de evitar a desordem e a destruição inerentes a tais conflitos, era estabelecer a instrução primária como obrigatória no Brasil, pois só 
ela poderia acabar com a fácil manipulação que as camadas populares supostamente sofriam e que resultava em movimentos como aquele de novembro de 1904. Enfim,

(...) se tratássemos já e já de decretar a instrução primária obrigatória, pondo a gente pobre e humilde a coberto da exploração dos que especulam com a sua ignorância, nem haveria levantes militares, nem haveria Port Arthur de sicários, nem gente bem intencionada mas inculta se amotinaria contra a vacinação (BILAC, 1904a: 1).

Portanto, a partir de ambos os trechos destacados, podemos depreender que a desordem social, concretizada por vezes através de movimentos de revolta popular, seria, para Olavo Bilac, produto em grande parte da ignorância das camadas iletradas, porém, mais importante é apreendermos a compreensão construída pelo autor quanto à instrução enquanto meio fundamental para sua prevenção, ou seja, para a garantia da ordem social, sobretudo pelo seu poder de conscientização. Afinal, uma vez alfabetizados, como Bilac implicitamente propôs, estariam os brasileiros livres da manipulação e ao mesmo tempo capazes de compreender, por exemplo, a positividade e utilidade das medidas modernizadoras aplicadas durante a gestão do prefeito-engenheiro Pereira Passos. Esta reflexão bilaquiana, que interpretava a alfabetização como o principal meio para uma adequada compreensão de mundo, tem as suas raízes na chamada pedagogia liberal tradicional (LUCKESI, 1992), já estabelecida em pleno início do século XX e baseada na ideia de que o indivíduo seria um receptor passivo dos conteúdos transmitidos pelas instituições educacionais, mais especificamente, pela figura do professor, considerada central para esta corrente filosófico-educacional.

A nosso ver, exemplar quanto ao fato de que tal corrente de pensamento fundamentava as reflexões de Olavo Bilac sobre a existência social do indivíduo contemporâneo, é o sentido de suas palavras que apontavam para a posse do conhecimento e da razão, ambos representados através da condição da alfabetização, como pré-requisito para que o indivíduo pudesse agir plena, consciente e acertadamente nas mais diversas esferas da vida social, inclusive diante de questões como a polêmica vacinação contra a varíola. Em suma, a difusão da educação primária era um dos mecanismos fundamentais, dentre os concebidos pelo poeta-jornalista, para garantir o progresso em terras brasileiras, pois, através dela é que as camadas populares poderiam 
compreender a utilidade de projetos como o concebido por Oswaldo Cruz e, em última instância, civilizar-se.

Outro exemplo interessante, relacionado ao entendimento bilaquiano da alfabetização, especificamente enquanto meio de acesso a uma compreensão de mundo que potencialmente garantiria a adesão do brasileiro à modernização que tanto exaltara, consta nas palavras que publicou sobre o recenseamento civil, também empreendido pela gestão municipal de Pereira Passos, em meados de 1906. A proposta, segundo o cronista Olavo Bilac, fundamental a uma racional e eficiente administração da cidade, não foi vista com bons olhos por boa parte da população carioca, sendo mais uma vez apontado o analfabetismo como uma das causas da desconfiança popular ante o projeto. De acordo com o autor, o analfabetismo impedia que a população percebesse a inexistência de qualquer relação entre a realização do recenseamento, medida de caráter estritamente estatístico, e o alistamento militar, então paralelamente organizado pelo Ministério da Guerra: "estas ideias, tão simples, tão claras, tão vulgares, não podem, desgraçadamente, ser eficazmente incutidas no ânimo de nossa população. Por quê? porque uma grande parte da nossa população não saber ler...” (BILAC, 1906c: 5). As palavras de Bilac evidenciavam a sua interpretação do analfabeto enquanto sujeito incapaz de compreender a realidade social na qual se encontrava inserido, daí advindo, por exemplo, males como o "furtar-se ao cumprimento de um dever social" de "grande utilidade" (BILAC, 1906c: $5)$ :

O povo, porém, não compreende isso. Se lhe não demonstrarem cabalmente que o recenseamento civil, organizado pela prefeitura, nada tem de comum com o alistamento militar, organizado pelo Ministério da Guerra, ele, apavorado pelo fantasma da Farda, há de mais uma vez furtar-se ao cumprimento de um dever social, que tão facilmente e com tão grande utilidade para todos pode ser cumprido. Como, porém, fazer essa demonstração àqueles que, por culpa e desídia do Estado, continuam aviltados pelo analfabetismo, moralmente cegos, tristemente mantidos na ignorância, privados da compreensão dos seus direitos e dos seus deveres? (BILAC, 1906c: 5).

Na verdade, uma plena e total "orientação" do cidadão brasileiro, através de sua inserção em espaços formais de educação, para a esperada adesão e apoio ao excludente modelo de sociedade que então se desenhava no Brasil republicano, obviamente era algo 
impossível, tendo em vista que tratamos de um momento histórico extremamente complexo no que se refere à atuação de agentes sociais e políticos "pró" e "contra" a ordem estabelecida. Exemplo importante de atuação contra hegemônica reside na militância dos grupos anarquistas que conseguiram significativa capacidade de influência sobre as classes trabalhadoras urbanas, para lutar contra a crescente exploração capitalista vigente no país. De todo modo, claro é que o poeta-jornalista tinha plena consciência de que a difusão da instrução por nossa população abrigava em si inúmeras possibilidades, tanto positivas, como a de conduzi-la ao apoio à modernização social que considerava fundamental, como negativas, dentre elas, o potencial de levá-la à contestação do excludente status quo republicano, através, por exemplo, da adesão a movimentos como o anarquista. Ou seja, Bilac percebia os limites da conformação ideológica que entendia como parte fundamental do processo educacional que pretendia ver difundido por nossa população. Quando chegou a se referir ao movimento anarquista e à atração que este exerceu nos meios operários coevos, o autor mostrara saber da impossibilidade de um consenso social que eliminasse possíveis movimentos de contestação à ordem constituída, embora tivesse consigo que conduzir os brasileiros para longe dos mesmos era importantíssimo, sobretudo através de sua inserção em espaços de formação profissional e educacional:

Ai de nós! A verdade é que a instrução é um vinho forte demais para certas cabeças. [...] Nas mãos de certos homens, o livro e o jornal são como fogo em mãos de criança. [...] Um pobre operário, sem família, sem conselho, sem religião, na perigosa idade em que os primeiros rebates do instinto da procriação acendem o sangue e desengonçam as molas do cérebro, apanha um dia o jornal e fica pasmado diante do mundo novo que se lhe abre diante dos olhos. Aquelas coisas nunca lidas fulguram na folha em traços de fogo: as ideias, ardentes e novas, sobem à cabeça do desgraçado, embebedam-no e desviam-no. [...] Nos papéis venenosos, que diz o apóstolo da vingança e do ódio [...]? Não lhe diz que pode haver na humildade e no sofrimento, muitas vezes, mais felicidade e mais consolo do que no poder e na glória. Não lhe diz que a dedicação, a resignação, a renúncia podem muitas vezes fazer mais do que a ponta acerada de um punhal (BILAC, 1900: 1).

Na ocasião, Olavo Bilac curiosamente abordou a questão da instrução contestando a ideia, que dizia ser muito comum à época, de que a "Carta de $\mathrm{ABC}$ é a salvação da 
humanidade", e ao mesmo tempo indicara que, depreender desta perspectiva, que "só ignorantes cometem crimes atrozes", era compartilhar de um posicionamento um tanto ingênuo. Por outro lado, deve-se frisar que imediatamente após tal constatação aparecia a sua interpretação de que "a instrução é um vinho forte demais para certas cabeças", o que é de fundamental importância para compreendermos que Olavo Bilac percebia que o aprendizado da leitura e da escrita trazia consigo um enorme potencial subversivo, sobretudo se o comum trabalhador entrasse em contato com doutrinas revolucionárias, tais como as anarquistas e socialistas. Na crônica, ambas eram bastante criticadas, sobretudo porque teoricamente incitavam os trabalhadores à revolta e ao ódio e não a uma postura de humildade e resignação: "Nos papéis venenosos, que diz o apóstolo da vingança [...]? Não lhe diz que [...] a dedicação, a resignação e a renúncia podem muitas vezes fazer mais do que aponta acerada de um punhal" (BILAC, 1900: 1). Contudo, deve ser destacado que subjacente a esta visão esboçada pelo autor carioca, constava a sua adesão à noção de "classes perigosas" (CHALHOUB, 1996: 20), comum nos meios políticos e intelectuais da época e que equivocadamente interpretava as classes mais desfavorecidas, devido à sua pobreza, como inclinadas aos vícios, crimes e à desordem ${ }^{5}$. Daí o sentido da perspectiva do autor de que havia uma tendência do trabalhador brasileiro à adesão a doutrinas subversivas, como a anarquista, a seu ver, intimamente relacionada a práticas violentas e criminosas: "O que ele compreende é aquilo que lhe dizem o panfleto sedicioso e o jornal sanguinário, ressumando suco de mandrágora e fel. O que o encanta é aquela apoteose do crime" (BILAC, 1900: 1). De qualquer forma, no que se refere à instrução, importante de ser retirado da crônica publicada na Gazeta de Notícias, é principalmente o entendimento de que Olavo Bilac acreditava que a difusão da instrução, enquanto principal solução para as mazelas vividas pela população brasileira e pelo país, deveria ser muito bem orientada, ou até mesmo tutelada, justamente para que não houvesse nocivos “desvios" na sua efetivação, a exemplo da possibilidade da adesão popular a movimentos de caráter subversivo, contrários à ordem republicana e burguesa estabelecida no país.

A questão da instrução primária e sua difusão, em verdade, aos olhos do poetajornalista, estavam intimamente ligadas não somente aos processos de conscientização e civilização das camadas populares, ambos, como vimos, muito importantes para a

\footnotetext{
${ }^{5}$ De acordo com Sidney Chalhoub, "a noção de que a pobreza de um indivíduo era fato suficiente para torná-lo um malfeitor potencial teve enormes consequências para a história subsequente de nosso país" (CHALHOUB, 1996: 23).
} 
conquista de sua adesão aos tempos modernos e às benesses que estes trariam para o país, mas fundamentalmente à possibilidade de eliminação da profunda exclusão social em que se encontravam. Ao contrário de interpretações equivocadas a respeito de Olavo Bilac, que o tomaram como um intelectual distante e insensível às mazelas dos segmentos populares, temos como evidente que o jornalista carioca forneceu contundentes amostras de que problemáticas sociais, como a abismal desigualdade socioeconômica que tanto afetava (e ainda afeta) a nossa população comum, em muito lhe preocupavam, sobretudo pelo fato de que não enxergava em seu tempo maiores esforços por parte das esferas governamentais em propor efetivas soluções nesse sentido. Assim, a falta de instrução, sobretudo em nível primário, enquanto mais uma mazela que obstaculizava Olavo Bilac em seus planos de modernização social, foi temática constante de seus escritos cronísticos e com algum destaque o autor chegou a ratificar que a educação carregava consigo o importante papel de ser um dos principais instrumentos de inclusão social de seu tempo. Inserido numa conjuntura política de ínfimos investimentos governamentais na área educacional, não foram poucas as cobranças do jornalista aos profissionais da política brasileira, no sentido de persuadi-los a conceder maior atenção àquela tarefa que considerava primordial, ou seja, a de instruir a população analfabeta. Em meados de maio de 1906, o futuro presidente Afonso Pena iniciava uma viagem por diversos Estados do país, a bordo do navio Maranhão, e Olavo Bilac não deixara passar a ocasião para ironicamente ressaltar que, para além da cultura nacional, o chefe de Estado iria se deparar com a triste realidade do difundido analfabetismo popular. Referindo-se a notas correntes na imprensa, que afirmavam que Afonso Pena prezaria em sua jornada pelo consumo de produtos oriundos da indústria nacional, o cronista carioca escrevera ao estadista em edição da Gazeta de Notícias:

Somente, já que S. Ex. assim revela a disposição de proteger tudo quanto é brasileiro, quero eu chamar a sua preciosa atenção para uma coisa bem nossa, bem brasileira, que S. Ex. encontrará a cada passo por essas cidades e por esses sertões, e que ao contrário das outras, não deve ser protegida: - a falta de instrução. S. Ex. verá que, nas cidades do litoral, onde residem os governos, há ainda algumas escolas (bem poucas em verdade!), em que se formam alguns homens conscientes e livres. Mas, por pouco que o viajante ilustre se embrenhe nos sertões, verá que o Brasil ainda está à espera de Alguém que o inicie nos mistérios do abecedário [...] Bem sei (ai! de mim!) que sou importuno e impertinente, vindo dizer a um homem eleito Presidente: "V. Ex. 
vai ter a honra de governar um povo de analfabetos!..." Que hei de fazer, porém, se lendo e relendo a mensagem de S. Ex. nela não encontrei a promessa decisiva e formal de que alguma coisa se fará, durante o seu governo, para dar instrução primária aos que a não têm? (BILAC, 1906b: 5).

Plenamente ciente do grave panorama da educação pública brasileira, Olavo Bilac, já no seu tempo de jornalista, revelou-se um árduo defensor da expansão da rede pública de ensino primário e um profundo conhecedor dos principais debates relativos às políticas governamentais para a área. Embora tivesse criticado Afonso Pena, ainda em 1906, por não ter explicitado maiores compromissos com a educação primária através de sua mensagem oficial, fato é que no decorrer do seu mandato, mais especificamente no ano de 1907, o referido presidente apresentou um projeto de reforma do ensino público, o qual visava auxiliar Estados e municípios no setor educacional (SILVA, 1990: 123). Manoel Bonfim, amigo de Olavo Bilac, que assumiu uma vaga de deputado durante as discussões do projeto, lutou intensamente neste momento, inclusive elaborando variadas emendas a fim de conquistar maiores ganhos para a causa da instrução primária. Contudo, nos importa que Olavo Bilac, através de sua crônica semanal, enfocou algumas das discussões que marcaram este contexto, dentre elas, a súbita valorização que a educação profissionalizante havia conquistado, o que acabou por lhe servir como impulso para ratificar o seu entendimento de que a expansão da educação primária deveria ser prioridade. Como pudemos depreender, aos olhos do cronista carioca, atentar para a educação primária significava atentar primeiramente para a inclusão social da extensa população analfabeta do país, em outros termos, ajudaria na "fabricação de gente" apta a viver de maneira autônoma em meio àquela sociedade brasileira em profunda transformação, mas que ainda era uma "terra de analfabetos" (BILAC, 1907a: 1):

Mas que lhe havemos de fazer, se isso é uma flagrante [...] verdade? Tão errados andavam os que apenas queriam fabricar bacharéis, como andam os que querem apenas fabricar ferreiros. O que nós devemos querer fabricar, antes de tudo, é gente: gente no sentido rigoroso e preciso da palavra, gente inteligente e consciente, capaz de escolher por si mesmo a profissão e o destino social que preferir. Todo o problema da instrução no Brasil se resume atualmente nisto: é preciso, preferentemente, urgentemente, e até exclusivamente, tratar já e já da difusão do ensino primário. (BILAC, 1907a: $1)$. 
Inexoravelmente ligada à ideia de que a difusão da instrução seria um dos privilegiados meios para a inclusão social de milhões de analfabetos brasileiros, constava a pretensão do autor de tê-la como instrumento para o combate à realidade de exclusão social e preconceito racial vivida pelos negros. Representando um significativo contingente da população brasileira, pode-se dizer que os negros, fossem libertos ou seus descendentes, não foram alvo de políticas públicas inclusivas, nem por parte do regime monárquico nem da República, cabendo-lhes as consequências da abismal desigualdade socioeconômica vigente no país e sofrer o arraigado preconceito de cor que, à época, ainda contava com a importante legitimação das emergentes teorias científicas de viés racial (SCHWARCZ, 1993). Deste modo, além de radicalmente contrário ao preconceito de cor (BILAC, 1906a: 3), Olavo Bilac por vezes demonstrou-se bastante preocupado com a dura realidade social dos negros no Brasil e a sua aguçada percepção sobre a difícil vida destes últimos, seguramente em muito se devia ao ativo envolvimento que teve com os movimentos abolicionista e republicano do último quartel do século XIX. Participar de seu desenvolvimento e sucesso seguramente possibilitou ao autor notar a ausência de significativos projetos de inclusão social para os negros, sobretudo após a efetivação da lei abolicionista de 13 de maio de 1888, assim como refletir a respeito de possíveis soluções para a difícil condição social em que foram mantidos. A situação dos negros brasileiros possuía ares de questão social para Olavo Bilac, que concebera a sua inserção em espaços educacionais formais como a principal solução para a marginalização que experimentavam na virada do século. $O$ poeta-jornalista tinha claro para si que a negligência governamental era a principal causa de tal situação e que somente o acesso à instrução não resolveria a sua realidade de exclusão:

Que fizemos nós, afinal? Proclamamos a liberdade dos cativos, mas não tratamos de assegurar a sua vida e a sua felicidade. Não os instruímos, não os educamos, não lhes demos trabalho [...]. Que escolas agrícolas, industriais ou profissionais fundamos, de 1888 até hoje, para transformar em verdadeiros cidadãos os homens que havíamos explorado como animais? Os que lutaram e venceram, lutaram e venceram sozinhos, sem o nosso auxílio; e não têm conta os que morreram, nesses sertões ignorados, à míngua de trabalho e de instrução, devorados pela miséria, pela ignorância, pelo alcoolismo, pelo abandono moral... (BILAC, 1907b: 1). 
Portanto, ainda que a perspectiva de Olavo Bilac tenha mais uma vez evidenciado a sua favorável inclinação pela preconceituosa noção de "classes perigosas", já que o trecho destacado interligava a condição de pobreza e exclusão dos negros aos vícios, relevamos que, do ponto de vista do autor, a sua emancipação social frente a tais males, então vistos como muito comuns às camadas mais desfavorecidas, deveria ser realizada principalmente pela adequada concessão de trabalho e educação. Obviamente as palavras de indignação de Bilac não protestavam visando garantir aos negros a igualdade social, afinal, eram caríssimos ao autor os processos de consolidação da República e do capitalismo no país; logo, a inclusão social que vislumbrava, através de espaços, como o educacional, e práticas, como a do trabalho formal, estava inexoravelmente determinada pelos padrões excludentes da ordem estabelecida.

Quanto à questão da instrução, a partir do ponto de vista do intelectual, Olavo Bilac, a título de conclusão, podemos afirmar que a mesma possuía lugar de destaque em seu projeto de modernização da nação brasileira. Seria a educação formal, sobretudo a primária, o principal instrumento "civilizador" de nossa população, já que esta, justamente pelo fato de ser maciçamente iletrada, era, para o poeta-jornalista, em grande parte incivilizada, ignorante e inclinada à desordem e à violência, e, portanto, mais do que necessitada das luzes do abecedário.

Aos olhos de Olavo Bilac, o analfabetismo popular era não apenas sinônimo de ignorância, porém, mais um elemento da realidade brasileira que ratificava o histórico quadro de atraso social do país. A proposição de soluções para tal atraso marcou diversas crônicas do autor carioca, a exemplo da ênfase que concedeu à necessidade de expansão da educação primária e à aprovação de sua obrigatoriedade. Medidas socialmente modernizadoras como estas, produziriam o "povo" que Olavo Bilac ainda não acreditava que o Brasil possuía, já que este não existiria "onde os analfabetos estão em maioria" (BILAC, 1904b: 3-4). Contudo, cabe frisar, como o jornalista nos permitiu depreender de suas crônicas, que a instrução possuía o papel fundamental da inculcação dos valores mais caros aos regimes republicano e burguês constituídos no país, dentre eles o culto à ordem, ao trabalho e à participação eleitoral, assim como carregaria consigo o poder de inclusão de camadas marginalizadas, principalmente nos âmbitos socioeconômico e político. 


\section{Fontes}

BILAC, Olavo (1900). Crônica. Gazeta de Notícias, 5 de agosto, p.1. (1903). Crônica. Gazeta de Notícias, 02 de agosto, p.1-2. (1904a). Crônica. Gazeta de Notícias, 20 de novembro, p.1. (1904b). Crônica. Kosmos, novembro de, p. 3-4. (1905a). Crônica. Gazeta de Notícias, 8 de janeiro, p.2. (1905b). Crônica. Gazeta de Notícias, 1 de outubro, p.5. (1905c). Crônica. Gazeta de Notícias, 19 de novembro, p.3. (1906a). Crônica. Gazeta de Notícias, 21 de janeiro, p.3. (1906b). Crônica. Gazeta de Notícias, 13 de maio, p.5. (1906c). Crônica. Gazeta de Notícias, 17 de junho, p.5. (1906d). Crônica. Kosmos, agosto de 1906d, p.3-4. (1907a). Ou bacharel ou ferreiro..., Correio Paulistano, 27 de setembro, p.1. (1907b). Crônica. Gazeta de Notícias, 19 de maio, p.1.

\section{Referências Bibliográficas}

BOURDIEU, Pierre (1968). Campo intelectual e projeto criador. In: POUILLON, Jean. et al (Orgs.). Problemas do estruturalismo. Rio de Janeiro: Zahar, pp. 105-145.

BOURDIEU, Pierre (1989). O poder simbólico. Rio de Janeiro: Ed. Bertrand. (1996). A ilusão biográfica. In: AMADO, Janaina; FERREIRA, Marieta de Moraes (Org.). Usos \& abusos da história oral. 8. ed. Rio de Janeiro: FGV, pp.183191.

CARVALHO, José Murilo de (1987). Os bestializados: o Rio de Janeiro e a república que não foi. São Paulo: Companhia das Letras.

CHALHOUB, Sidney (1996). Cidade Febril: cortiços e epidemias na corte imperial. São Paulo: Companhia das Letras.

DIMAS, Antônio (2006). Bilac, o jornalista. São Paulo: Imprensa Oficial do Estado de São Paulo, Edusp, Editora da Unicamp, 3 v.

ENGEL, Magali Gouveia (2004). Modernidade, dominação e resistência: as relações entre capital e trabalho sob a ótica de João do Rio. Revista Tempo, n. 17, pp.53-78, abr. Disponível em: <http://www.historia.uff.br/tempo/artigos_dossie/artg174.pdf $>$. Acesso em: 15 de jul. 2014.

(2006). Povo, política e cultura: um diálogo entre intelectuais da Primeira República. Anais do XII Encontro Regional de História: usos do passado. Rio de Janeiro, ANPUH-RJ. Disponível em: <http://www.rj.anpuh.org/resources/rj/Anais/2006/conferencias/Magali\%20Gouve ia\%20Engel.pdf $>$. Acesso em: 20 de ago. 2014.

(2008). Os intelectuais e a Liga de Defesa Nacional: por um projeto hegemônico de Brasil. Anais do V Simpósio Estado e Poder: Hegemonia. Niterói, Vício de Leitura.

(2010). A Liga de Defesa Nacional como partido: os intelectuais e a construção da hegemonia burguesa. Revista Electrónica de Estudios Latinoamericanos, vol. 8, n. 27, pp. 3-18, janeiro - março. 
HANSEN, Patrícia Santos (2007). Brasil, um país novo: literatura cívico-pedagógica e a construção de um ideal de infância brasileira na Primeira República. Tese (Doutorado em História). Universidade de São Paulo, São Paulo.

LUCKESI, Carlos Cipriano (1992). Filosofia da educação. São Paulo: Cortez Editora.

MAGALHÃES JÚNIOR, Raymundo (1974). Olavo Bilac e sua época. Rio de Janeiro: Ed. Americana.

SCHWARCZ, Lilia Moritz (1993). O espetáculo das raças: cientistas, instituições e questão racial no Brasil, 1870-1930. São Paulo: Companhia das Letras.

SILVA, José Maria de Oliveira (1990). Salvar a América - Educação e História: Nuances do Radicalismo Republicano em Manoel Bonfim. Revista Brasileira de História, vol. 9, n. 19, pp.115-134, set.1989/fev.

SIMÕES JÚNIOR, Álvaro Santos (2003/2004). A contribuição de Bilac para a crônica brasileira. O eixo e a roda, vol. 9/10, pp.235-246. Disponível em: <http://www.letras.ufmg.br/poslit/08_publicacoes_txt/er_9-10/er09_ass.pdf>. Acesso em: 18 de set. 2014. (2007). A sátira do parnaso. São Paulo: Ed. UNESP.

Artigo recebido em 05 de janeiro de 2015.

Aprovado em 15 de junho de 2015. 